\title{
PENGARUH PEMBERIAN MAKANAN PENDAMPING ASI ( MP - ASI) DINI TERHADAP KEJADIAN KEKURANGAN ENERGI PROTEIN (KEP) PADA ANAK UMUR 0 - 24 BULAN DI WILAYAH KOTA KEDIRI
}

\author{
Ira Titisari, Susanti Pratamaningtyas, Eny Sendra, \\ Prodi Kebidanan Kediri Jl.KH.Wakhid Hasyim 64 B Kediri \\ Email: iratitisari@ymail.com
}

Abstrac

Should we know that Mother's Milk Complementary Foods is begin giving when someday after the baby was born. This is deficient think, because Mother's Milk Complementary Foods present can make malnutrition consist or disturb child development (Energy-Protein Malnutrition). The destination of this research is to find out effect of giving too early Mother's Milk complementary Foods with Energy-Protein Malnutrition incident to children on zero until twenty four months old. The methode of this research is the corelation with analitic case control characteristic that is eight child as case and eight others as control of fill up inclusion criteria. The samples will take by purposive sampling tehnis. The finishing data collection are using questionaire by weight and height measurement. The data analitic are using fisher exact probability test with 5\% significancy. The result of this research is giving Mother's Milk Complementary Foods to 87,5\% Energy-Protein Malnutrition group and 25\% non Energy-Protein Malnutrition is not timely. 100\% Energy-Protein Malnutrition is nasty. There is an effect of giving too early Mother's Food Complementary Foods in Energy-Protein Malnutrition accident on children at zero untill six months old. Be expected for the health personnel to give information and counseling about to give too early Mother's Milk Complementary Foods about effect and the interval, at the same time for a children whio has Energy-Protein Malnutrition must give supplementary food that appropriate with the local program and integrated by Department of health.

Keywords $=$ Giving too early Mother's Milk Complementary Foods, Energy-Protein Malnutrition

\section{Pendahuluan}

Diperkirakan 100 juta anak menderita gizi kurang pada tingkat sedang dan berat (KEP), yang merupakan keadaan defisiensi gizi paling umum dijumpai di dunia. Golongan anak yang berstatus gizi kurang memiliki risiko kematian yang lebih tinggi daripada anak dengan status gizi baik.

KEP merupakan salah satu masalah kesehatan anak di Indonesia atau di negara berkembang lainya. Angka kejadian tertinggi yaitu pada anak balita yang dapat berakibat gangguan pertumbuhan dan perkembangan termasuk kecerdasan anak (http://www.google.gizi net.com.2006).
Prevalensi gizi kurang pada balita dan tahun ke tahun mengalami penurunan yang cukup berarti. Pada tahun 1989, preva!ensi balita bergizi kurang (Skor Z Berat Badan menurut Umur) mencapai 37,5\%. Pada tahun-tahun berikutnya prevalensi kurang gizi balita terus mengalami penurunan sehingga pada tahun 2000 prevalensi kurang gizi balita menjadi 24,7\%. Menurut Depkes 2004 saat Indonesia mengalami krisis multi dimensi, prevalensi gizi kurang mengalami kenaikan lagi berturut-turut menjadi $26,1 \%, 27,3 \%$ dan $27,5 \%$ pada tahun 2001,2002 dan 2003 (Hamam Hadi, 2005) 
Pada tahun 2009 Departemen Kesehatan di Indonesia membuat berbagai program untuk mengatasi masalah gizi kurang pada balita. Seperti, program penanggulangan yang meliputi, pendidikan gizi, pemberdayaan masyarakat melalui pembentukan keluarga sadar gizi (kadarzi), peningkatan survellans gizi. Semua itu dilakukan dengan tiga strategi utama yakni, pemberdayaan masyarakat, peningkatan akses terhadap pelayanan kesehatan berkualitas, monitoring dan informasi kesehatan. (http:/www. menkokesra. 90.id).

Peran serta orang tua dalam pemberian gizi yang baik pada balita sangat berpengaruh, karena gizi buruk dan gizi kurang pada balita terjadi melalui proses yang panjang dan utamanya sangat ditentukan oleh pemenuhan kebutuhan nutrisi pada masa pertumbuhan balita yakni, sejak janin masih dalam kandungan hingga bayi dilahirkan sampai berusia dua tahun.(Riri Wijaya,2006).

Menurut laporan organisasi kesehatan WHO, permasalahan gizi dapat ditunjukkan dengan besarnya angka kejadian gizi buruk yang menunjukkan kesehatan masyarakat Indonesia terendah di ASEAN, dan menduki peringkat ke 142 dari 170 negara. Data WHO menyebutkan angka kejadian gizi buruk pada balita tahun 2002 meningkat menjadi 8,3\% dan gizi kurang 27,5\%, serta pada tahun 2005 kejadian gizi buruk naik lagi menjadi $8,8 \%$ dan gizi kurang 28\% (Dina, 2007).

Tahun 2007 lalu tercatat sebanyak 4 juta balita Indonesia mengalami gizi kurang dan 700.000 anak masuk kedalam kategori gizi buruk. Pendapat serupa dikemukakan dari Rachmat sentika, Sp.A, MARS, dari tim Ahli Anak komisi perlindungan Anak Indonesia, Rachmat menilai konduisi Asupan gizi balita di Indonesia memprihatinakn, penyebabnya asupan gizi yang kurang dan perubahan pola asuh yang tidak terpantau baik. Ahli gizi anak dari Istitusi Pertanian Bogor, Prof Dr Ir Ali Khomsan MS dan TIM Ahli anak dari komisi Perlindungan Anak Indonesia tb Rachmat sentika, senin (11/8) di Jakarta.

Ali khomsan mengatakan, akar masalah yang menyebabkan tingginya angka anak yang menderita kurang gizi karena anak-anak makan seadanya dan dominan karbohidrat. Dalam koferensi pers yang diselenggarakan oleh kondisi untuk Indonesia sehat mengenai kampanye "Pentingnya Gizi Anak" dr.Dini Latief MSC, dari direktorat jendrl Bina kesehatan masyarakat, Depkeskesos mengatakan, meski pavelensi gizi buruk sudah menurun, dari $8,1 \&$ dari 1,7 juta balita yang menderita gizi kurang. Pada tahun 1999 menjadi 7,5\% pada tahun 2000 berdasarkan survey sosial ekonomi nasional (Susenas) namun jumlah nominlnya masih terhitung tinggi, yaitu 160.000 balita (Dini, 2007).

Hasil penelitian menyatakan bahwa keadaan KEP pada bayi dan anak disebabkan pemberian MP-ASI yang tidak tepat, baik secara kualitas maupun kuantitasnya.(Parenting Islami 2008). Sesuai dengan anjuran WHO bahwa MPASI diberikan paling cepat pada usia 6 bulan dengan alasan kematangan saluran cerna, kematangan mekanisme menelan dan pertumbuhan gigi geligi terjadi pada usia 4-6 bulan.( Damayanti R.Sjarif, 2007).

Berdasarkan latar belakang diatas maka peneliti tertarik untuk melakukan penelitian tentang pengaruh pemberian MP-ASI dini terhadap kejadian KEP pada anak umur $0-24$ bulan.

\section{Tujuan Penelitian}

a. Tujuan Umum

Untuk mengetahui pengaruh pemberian MP-ASI dini terhadap kejadian KEP pada anak umur $0-24$ bulan di wilayah Kota Kediri

b. Tujuan Khusus

1. Mengetahui usia pemberian MPASI dini pada anak umur $00-24$ bulan di wilayah Kota Kediri. 
2. Mengetahui kejadian KEP pada anak umur $0-24$ bulan di wilayah kota Kediri

3. Menganalisa pengaruh pemberian MP-ASI dini terhadap kejadian KEP pada anak umur $0-24$ bulan di wilayah Kota Kediri

\section{Metode Penelitian}

Populasi dalam penelitian ini adalah semua anak umur 0 - 24 bulan yang ada di Wilayah Kota Kediri. Sampel yang diambil dalam penelitian ini adalah : semua anak umur $0-24$ bulan yang mengalami KEP yang ada di wilayah Kota Kediri yaitu sebanyak 8 balita. Sebagai kontrol adalah anak umur $0-24$ bulan yang tidak mengalami KEP yang ada di wilayah Kota Kediri yaitu sebanyak 8 balita. Adapun teknik samping yang digunakan adalah purposive sampling.

\section{KRITERIA SAMPEL}

a. Kriteria Inklusi

1). Anak umur $0-24$ bulan yang mengalami KEP

2). Anak umur 0 - 24 bulan yang mengalami KEP yang diberi MPASI

3). Anak umur $0-24$ bulan yang tidak mengalami KEP yang diberi MP-ASI

4). Anak umur $0-24$ bulan yang mengalami KEP yang orang tuanya bersedia anaknya menjadi responden

5). Anak umur $0-24$ bulan yang tidak mengalami KEP yang orang tuanya bersedia anaknya menjadi responden.

\section{Variabel Penelitian}

Variabel Independen (Variabel Bebas)

Variabel independen dalam penelitian ini adalah awal pemberian makanan pendamping ASI (MP-ASI).

Variabel Dependen (Variabel Terikat) Variabel dependen dalam penelitian ini adalah Dalam penelitian ini variabel tergantungnya adalah kekurangan energi protein (KEP) pada balita.
ANALISA DATA

Untuk mengetahui hubungan antara 2 variabel maka peneliti melakukan analisa korelasi dengan menggunakan uji Fisher Exact Probability Test :

Rumus : $\mathrm{P}=\frac{(\mathrm{A}+\mathrm{B}) !(\mathrm{C}+\mathrm{D}) !(\mathrm{A}+\mathrm{C}) !(\mathrm{B}+\mathrm{D}) !}{}$

$\mathrm{N} ! \mathrm{A} ! \mathrm{B} ! \mathrm{C} ! \mathrm{D} !$

Dengan taraf signifikansi $5 \%(0,05)$

\section{HASIL PENELITIAN}

1. Waktu pemberian MP ASI

Berdasarkan data dari 16 kuesioner yang dibagikan kepada kelompok kasus dan kelompok kontrol untuk mengetahui kapan pemberian MPASI dini (tepat waktu dan tidak tepat waktu) yang diberikan pada anak umur $0-24$ bulan didapatkan hasil sebagai berikut:

\begin{tabular}{|c|l|c|c|}
\hline No & $\begin{array}{l}\text { Pemberian } \\
\text { MP-ASI }\end{array}$ & Jumlah & Prosentase (\%) \\
\hline 1 & $\begin{array}{l}\text { Tepat } \\
\text { waktu }\end{array}$ & 7 & 43,75 \\
\hline 2 & $\begin{array}{l}\text { Tidak tepat } \\
\text { waktu }\end{array}$ & 9 & 56,25 \\
\hline & Jumlah & 16 & 100 \\
\hline
\end{tabular}

2. Kejadian Gizi baik dan buruk berdasarkan tinggi badan / berat badan

Berdasarkan data dari 16 responden dengan usia anak $0-24$ bulan baik pada kelompok kasus maupun kelompok kontrol didapatkan hasil sebagai berikut: 
Tabel 1. Distribusi kejadian gizi baik \& gizi buruk berdasarkan TB/BB

\begin{tabular}{|c|l|c|c|c|c|}
\hline \multirow{2}{*}{ NO } & \multicolumn{1}{|c|}{ TB/BB } & \multicolumn{2}{c|}{ GIZI BAIK } & \multicolumn{2}{c|}{$\begin{array}{c}\text { GIZI } \\
\text { BURUK }\end{array}$} \\
\cline { 3 - 6 } & & Jml & $\%$ & $\begin{array}{c}\text { Jm } \\
1\end{array}$ & $\%$ \\
\hline 1 & $73 \mathrm{~cm} / 9 \mathrm{~kg}$ & 1 & 6,25 & & \\
\hline 2 & $81 \mathrm{~cm} / 9,6 \mathrm{~kg}$ & 1 & 6,25 & & \\
\hline 3 & $\begin{array}{l}81,5 \mathrm{~cm} / 9,2 \\
\mathrm{~kg}\end{array}$ & 1 & 6,25 & & \\
\hline 4 & $58 \mathrm{~cm} / 7,4 \mathrm{~kg}$ & 1 & 6,25 & & \\
\hline 5 & $58 \mathrm{~cm} / 6,8 \mathrm{~kg}$ & 1 & 6,25 & & \\
\hline 6 & $68 \mathrm{~cm} / 9 \mathrm{~kg}$ & 1 & 6,25 & & \\
\hline 7 & $70 \mathrm{~cm} / 9 \mathrm{~kg}$ & 1 & 6,25 & & \\
\hline 8 & $55 \mathrm{~cm} / 9 \mathrm{~kg}$ & 1 & 6,25 & & \\
\hline 9 & $71 \mathrm{~cm} / 7,2 \mathrm{~kg}$ & & & 1 & 6,25 \\
\hline 10 & $76,5 \mathrm{~cm} / 7,2$ & & & 1 & 6,25 \\
\hline 11 & $\mathrm{~kg}$ & & & & \\
\hline 12 & $72 \mathrm{~cm} / 6,4 \mathrm{~kg}$ & & & 1 & 6,25 \\
\hline 13 & $79 \mathrm{~cm} / 7,8 \mathrm{~kg}$ & & & 1 & 6,25 \\
\hline 14 & $75 \mathrm{~cm} / 7 \mathrm{~kg}$ & & & 1 & 6,25 \\
\hline 15 & $80 \mathrm{~cm} / 7 \mathrm{~kg}$ & & & 1 & 6,25 \\
\hline 16 & $68 \mathrm{~cm} / 5 \mathrm{~kg}$ & & & 1 & 6,25 \\
\hline
\end{tabular}

Tabel 2. Distribusi usia berdasarkan $\mathrm{TB} / \mathrm{BB}$

\begin{tabular}{|c|l|c|c|c|c|}
\hline \multirow{2}{*}{ NO } & \multirow{2}{*}{ TB/BB } & \multicolumn{2}{|c|}{$\begin{array}{c}\text { Usia } 0-1 \\
\text { tahun }\end{array}$} & \multicolumn{2}{c|}{$\begin{array}{c}\text { Usia } \geq 1 \text { th } \\
-2 \text { th }\end{array}$} \\
\cline { 3 - 6 } & & Jml & $\%$ & Jml & $\%$ \\
\hline 1 & $73 \mathrm{~cm} / 9 \mathrm{~kg}$ & 1 & 6,25 & & \\
\hline 2 & $81 \mathrm{~cm} / 9,6 \mathrm{~kg}$ & 1 & 6,25 & & \\
\hline 3 & $81,5 \mathrm{~cm} / 9,2 \mathrm{~kg}$ & 1 & 6,25 & & \\
\hline 4 & $58 \mathrm{~cm} / 7,4 \mathrm{~kg}$ & 1 & 6,25 & & \\
\hline 5 & $58 \mathrm{~cm} / 6,8 \mathrm{~kg}$ & 1 & 6,25 & & \\
\hline 6 & $68 \mathrm{~cm} / 9 \mathrm{~kg}$ & 1 & 6,25 & & \\
\hline 7 & $70 \mathrm{~cm} / 9 \mathrm{~kg}$ & 1 & 6,25 & & \\
\hline 8 & $55 \mathrm{~cm} / 9 \mathrm{~kg}$ & 1 & 6,25 & & \\
\hline 9 & $71 \mathrm{~cm} / 7,2 \mathrm{~kg}$ & & & 1 & 6,25 \\
\hline 10 & $76,5 \mathrm{~cm} / 7,2 \mathrm{~kg}$ & & & 1 & 6,25 \\
\hline 11 & $72 \mathrm{~cm} / 6,4 \mathrm{~kg}$ & & & 1 & 6,25 \\
\hline 12 & $78 \mathrm{~cm} / 7,4 \mathrm{~kg}$ & & & 1 & 6,25 \\
\hline 13 & $79 \mathrm{~cm} / 7,8 \mathrm{~kg}$ & & & 1 & 6,25 \\
\hline 14 & $75 \mathrm{~cm} / 7 \mathrm{~kg}$ & & & 1 & 6,25 \\
\hline 15 & $80 \mathrm{~cm} / 7 \mathrm{~kg}$ & & & 1 & 6,25 \\
\hline 16 & $68 \mathrm{~cm} / 5 \mathrm{~kg}$ & 1 & 6,25 & & \\
\hline
\end{tabular}

3. Pengaruh pemberian MP ASI terhadap kejadian diare

Kejadian KEP ditentukan berdasarkan parameter BB/TB sehingga diperoleh status gizi balita. Status gizi diklasifikasikan sebagai berikut buruk, kurang, baik, dan lebih.

Tabel 3. Distribusi pengaruh waktu pemberian MP-ASI terhadap kejadian gizi buruk dan gizi baik

\begin{tabular}{|c|l|c|c|c|c|}
\hline \multirow{2}{*}{ No } & \multirow{2}{*}{$\begin{array}{c}\text { Pemberian } \\
\text { MP-ASI }\end{array}$} & \multicolumn{2}{|c|}{ Gizi buruk } & \multicolumn{2}{c|}{ Gizi baik } \\
\cline { 3 - 6 } & Jml & $(\%)$ & Jml & $(\%)$ \\
\hline 1 & Tepat waktu & 1 & 12,5 & 6 & 75 \\
\hline 2 & $\begin{array}{l}\text { Tidak tepat } \\
\text { waktu }\end{array}$ & 7 & 87,5 & 2 & 25 \\
\hline & \begin{tabular}{l} 
Jumlah \\
\cline { 2 - 6 }
\end{tabular} & 8 & 100 & 8 & 100 \\
\hline
\end{tabular}

Dari hasil pendataan yang sudah ditabulasi kemudian dimasukkan di dalam program SPSS secara komputerisasi di dapatkan hasil 0,041 lebih kecil dari 0,05 sehingga didapatkan adanya pengaruh pemberian MP-ASI dini terhadap kejadian KEP

\section{PEMBAHASAN}

1. Waktu pemberian MP ASI

Berdasarkan hasil penelitian yang dilakukan dengan pengisian kuesioner terdapat 8 responden sebagai kasus dan 8 responden sebagai kontrol diperoleh hasil : pada kelompok kasus terdapat 1 responden $(12,5 \%)$ memperoleh MP-ASI tepat waktu sedangkan 7 responden $(87,5 \%)$ tidak tepat waktu. Pada kelompok kontrol terdapat 6 responden $(75 \%)$ memperoleh MP-ASI tepat waktu, 2 responden $(25 \%)$ tidak tepat waktu. Pemberian MP-ASI yang terlalu dini (tidak tepat waktu) pada kelompok kasus yang menduduki prosentase terbesar mungkin di pengaruhi oleh faktor sosial dimana di wilayah Kota Kediri banyak ibu-ibu yang masih mengikuti tradisi lama yaitu pemberian makanan lembek pada bayi dengan beranggapan dapat meningkatkan tumbuh kembang anaknya. Atau juga karena kurangnya pengetahuan ibu tentang manfaat MP-ASI yang hanya sebagai pelengkap ASI bukan untuk menggantikan ASI. Jadi ibu-ibu 
beranggapan bahwa MP-ASI sebagai makanan pelengkap kebutuhan bayi. Dan bayi akan merasa kenyang dengan makanan tambahan yang diberikan. Hal ini sesuai dengan pernyataan Soraya, Luluk L (2005) bahwa banyak sekali alasan mengapa orang tua memberikan MP-ASI terlalu dini, umumnya banyak ibu yang beranggapan kalau anaknya kelaparan dan akan tidur nyenyak jika diberi makan.

Namun disisi lain ada beberapa kondisi yang menyebabkan pemberian MP-ASI terlalu dini, seperti dalam Sunartyo, Nano (2002) yang menyebutkan bahwa sebagian bayi mungkin dapat tumbuh dengan normal sampai umur 6 bulan hanya dengan ASI, tetapi ada sebagian bayi yang memerlukan banyak energi banyak energi dan zat-zat gizi lain daripada yang terdapat dalam ASI.

\section{Kejadian KEP}

Dari hasil penelitian diatas dapat diketahui bahwa jenis kejadian KEP di wilayah Kota Kediri adalah jenis KEP buruk 8 orang $(100 \%)$. Hal ini mungkin dipengaruhi oleh adanya faktor sosial ekonomi, sehingga mempengaruhi gangguan dan penyimpangan pemberian asupan gizi pada anak. Selain itu adanya pantangan untuk menggunakan bahan makanan tertentu (terutama terhadap balita serta ibu hamil dan menyusui) yang sudah turun temurun yang diperoleh dari budaya keluarga juga dapat memicu terjadinya KEP. Dan juga adanya budaya pantang makanan bagi para ibu setelah melahirkan sehingga para ibu tidak memperoleh gizi yang cukup. Dengan demikian bayi yang disusuinya tidak mendapat ASI yang cukup energi dan protein sedangkan pemberian pengganti ASI maupun makanan tambahan lainnya tidak dilakukan sesuai dengan kebutuhan gizi anak. KEP merupakan salah satu gangguan gizi akibat kurangnya asupan energi dan protein. Hal ini sesuai dengan pernyataan Uripni, Vera (2004) yang menyebutkan bahwa sebab-sebab kurangnya asupan energi dan protein antara lain makanan yang tersedia kurang mengandung energi, nafsu makan anak terganggu sehingga penyerapan sari makanan dalam usus terganggu, kebutuhan yang meningkat, misalnya karena penyakit infeksi yang tidak diimbangi dengan asupan yang memadai.

3. Pengaruh pemberian MP ASI terhadap kejadian KEP

Dari hasil analisa data dengan menggunakan Fisher Exact Probability Test dapatka nilai $\mathrm{P}$ hitung kurang dari 0 , 05. Artinya ada pengaruh antara pemberian MP-ASI dini dengan kejadian KEP pada anak umur $0-24$ bulan. Banyak faktor yang menyebabkan terjadinya KEP pada anak, salah satu diantaranya disebabkan oleh rendahnya konsumsi energi dan protein dalam makanan yang dimakan sehari-hari. Selain itu faktor ekonomi, sosial, budaya, dan pemberian MP-ASI yang terlalu dini atau tidak tepat waktu dapat mengakibatkan terjadinya malnutrisi / gangguan pertumbuhan anak (KEP).

Dari beberapa kasus pemberian MPASI dini memang dapat menyebabkan KEP. Hal ini disebabkan makanan yang diberikan kurang mengandung energi dan protein, seperti apa yang dikemukakan Nano Sunartyo (2006) bahwa pemberian MP-ASI hendaknya memenuhi beberapa syarat yaitu makanan harus memiliki nilai energi dan protein yang tinggi, bersifat padat gizi dan berserat lunak, memiliki nilai suplementasi yang baik, memiliki komposisi vitamin dan mineral dalam jumlah yang cukup, tidak hanya dapat menimbulkan rasa kenyang saja, dapat diterima oleh alat pencernaan bayi dengan baik. Sebaiknya MP-ASI mulai diberikan saat usia bayi 6 bulan, pada usia di bawah 6 bulan sistem pencernaan bayi belum memenuhi enzim untuk mencerna makanan. Pernyataan Luluk L Soraya (2005) bahwa saat bayi berumur 6 bulan ke atas sistem pencernaannya sudah relatif 
sempurna dan siap menerima MP-ASI, mengurangi resiko terkena alergi akibat pada makanan saat bayi berumur $<6$ bulan, menunda pemberian MP-ASI hingga 6 bulan melindungi bayi dari KEP dan memberikan perlindungan ekstra dan bebas dari berbagai penyakit.

\section{KESIMPULAN}

Berdasarkan hasil penelitian dan hasil analisa yang dilakukan peneliti, didapatkan hasil bahwa ada pengaruh antara pemberian makanan pendamping ASI (MP-ASI) dini terhadap kejadian kekurangan energi protein (KEP), maka peneliti dapat mengambil kesimpulan sebagai berikut :

a. Pemberian Makanan Pendamping ASI (MP-ASI) di wilayah Kota Kediri pada kelompok KEP sebagian besar diberikan sebelum pada usia 6 bulan sebanyak 87,5\% dan pada kelompok tidak KEP sebagian besar tepat waktu sebanyak $75 \%$.

b. Kejadian KEP di wilayah Kota Kediri pada kelompok KEP (gizi buruk) sebanayak $100 \%$

c. Ada pengaruh pemberian makanan pendamping ASI (MP-ASI) dini terhadap kejadian kekurangan energi protein (KEP) pada anak umur 0-24 bulan di wilayah Kota Kediri.

\section{SARAN}

Dari hasil penelitian yang telah dilakukan di wilayah Kota Kediri selama bulan September 2008 diharapkan :

a. Bagi Tempat Penelitian

1. Peningkatan kerjasama antara dinas kesehatan dengan tenaga kesehatan setempat dalam memberikan informasi tentang dampak pemberian MP-ASI dini pada anak.

2. Perlunya peningkatan penyuluhan tentang usia yang tepat untuk memberikan MP-ASI yang dilakukan oleh tenaga kesehatan kepada masyarakat setempat (misalnya pada saat Posyandu).
3. Perlunya pemberian makanan tambahan untuk anak yang sudah mengalami KEP yang berkaiatan dengan program setempat (Puskesmas)

\section{DAFTAR PUSTAKA}

Suharsimi Arikunto. (2002). Prosedur Penelitian Suatu Pendekatan Praktik, Jakarta: Rineka Cipta.

Arisman. (2004). Gizi Dalam Daur Kehidupan. Jakarta : EGC.

Aritonang, I. 09 Februari 2005. Kurang Energi Protein. http://www.info@gizi.net.com.16 Agustus 2006.

E.Fajri. (2002). Kamus Besar Bahasa Indonesia. Jakarta : Fajar Mulya.

Iqbal Hasan. (2004). Analisis Data Penelitian dengan Statistik, Jakarta: PT. Bumi Aksara.

Widodo Judarwanto. 08 Juni 2005. Kurang Energi Protein. Http://www.info@gizi.net.com.13 Februari 2006.

Damayanti R.Sjarif. (2007). Kapan Mulai Memberi makanan Pendamping ASI (1)

http://www.sahabatnestle.co.id/hom ev $2 / \mathrm{main} /$ infant $/$ main .asp? page=arti cle\&id=1397

Dini Kasdu. (2005). Makanan Sehat Untuk Bayi, Jakarta: 3G Publisher.

Dyah Krisnanuti. (2002). Menyiapkan Makanan Pendamping ASI, Jakarta: Puspa Swara.

Hamam Hadi. (2005). Beban Ganda Masalah Gizi Dan Implikasi Nya Terhadap Kebijakan Pembangunan Kesehatan Nasional www.gizi.net/download/Beban\%20 ganda\%20masalah\%20gizi.pdf

Moersintowarti B. Narendra (2002). Tumbuh Kembang Anak dan Remaja. Jakarta: Sagung Seto.

Y. Neney. 15 Juni 2005. Gizi Buruk, Ancaman Generasi yang Hilang. Http://www.manarchive.com/Balita-anda@Balitaanda.com. 9 Januari 2007. 
Nestle. (1999). Energi Protein KEP dan Pencegahannya.

Soekidjo Notoatmodjo. (2005). Metodologi Penelitian Kesehatan, Jakarta : Rineka Cipta.

Nursalam. (2003). Konsep dan Penerapan Metodologi Penelitian Ilmu Keperawatan : Pedoman Skripsi, Tesis dan Instrumen Penelitian Keperawatan, Jakarta: Salemba Medika.

Poppy Kumala, dkk. (1998). Kamus Saku Kedokteran Dorland. Jakarta : EGC.

W.J.S. Poerwodarminto (2001). Kamus Besar Bahasa Indonesia. Jakarta : Yayasan Bina Pustaka Tama.

Solihin Pudjiadi. (2001). Ilmu Gizi Klinis Pada Anak, Jakarta: FKUI.

Tuti Soenardi. (2004). Makanan untuk Tumbuh Kembang Bayi, Jakarta: Gramedia Pustaka Utama.

Sudigdo Sastroasmoro. (1995). DasarDasar Metodologi Penelitian Klinis. Jakarta : Binarupa Aksara.

Luluk L. Soraya. 26 Maret 2005. Resiko Pemberian MP-ASI Dini. Http://www.keluarga syfaBlogspot.com.16 Agustus 2006.

Sugiyono. (2004). Metode Penelitian Administrasi, Bandung : Alfabeta.

Sugiyono. (2004). Statistika Untuk Penelitian, Bandung : Alfabeta.

Suhardjo. (2003). Pemberian Makanan Pada Bayi dan Anak. Yogyakarta.

Dina Agoes Sulistijani. (2001). Menjaga Kesehatan Bayi dan Balita, Jakarta: Puspa Swara.

Nano Sunartyo. (2005). Panduan Merawat Bayi dan Balita. Yogyakarta : Diva Press.

Supariasa, IDN. (2001). Penilaian Status Gizi, Jakarta: EGC.

Vera Uripni. (2004). Menu Sehat untuk Balita, Jakarta, Puspa Swara.

WHO. (2003). Pemberian Makanan Tambahan, Jakarta: EGC. 